\title{
Contrasting Cases: Students' Experiences in an Active-Learning Biology Classroom
}

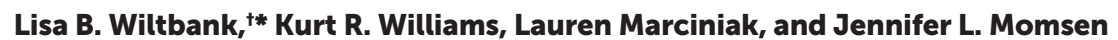

Department of Biological Sciences, North Dakota State University, Fargo, ND 58105

\begin{abstract}
In this qualitative study, we examined the process of active learning from the perspective of undergraduate students in a high-enrollment introductory biology class. Eight students participated in a series of five interviews throughout the semester that examined their experiences during and after class. Grades were collected for each student at regular time points throughout the semester. Here, we present in-depth case studies of four students who described profoundly different responses to the same in-class learning tasks. We particularly highlight variation in students' self-reported engagement, as engagement is thought to be a key element of successful active learning. Finally, we map each student's self-reported engagement and the grades that he or she received. In each case, we found that grades failed to capture some aspects of the active-learning experience that students found important.
\end{abstract}

\section{INTRODUCTION}

Historically, lecture has been the primary method for teaching large undergraduate science classes, but in recent decades, active-learning pedagogies have been gaining support from the scientific community (American Association for the Advancement of Science [AAAS], 2011; Waldrop, 2015; McLaughlin and Metz, 2016). One driving force for this transformation is a large body of literature that suggests performance benefits of active-learning methods over lecture (Prince, 2004; Armbruster et al., 2009; Freeman et al., 2011; Haak et al., 2011). In these studies, and most research about active learning, the conclusions largely address two research questions, commonly articulated as "Does active learning work?" and "What works best?" To answer these questions, studies seek to include many students and classes, as greater sample sizes offer an advantage in making more reliable predictions across populations. This large sample approach is akin to taking a picture with a wide-angle lens, which has the benefit of providing the viewer with a sense of the complete scene.

If we instead choose to "zoom in" on a small section of the active-learning picture-the experiences of a few students-this new viewpoint may reveal details about individual students that are not visible from a wider perspective. Zooming in on individual students could offer key insights for the interpretation of large sample size, wide-angle studies. Sometimes the experiences of individual students are dismissed as anecdotal. Indeed, small sample size studies, in contrast to large-scale experimental or survey studies, are not typically used in social science research to predict the behavior of a population or to determine the distribution of a phenomenon (Merriam, 2009). Small-sample qualitative studies should not be taken as an appraisal of whether a teaching strategy is effective for a majority of students ("What works?"). What in-depth qualitative studies do provide are concrete, context-dependent examples in an authentic environment (Flyvbjerg, 2006; Gouvea, 2017). Case studies can serve to illustrate how a theory plays out in the real world (Siggelkow, 2007). In this study, we explored the active-learning process on the level of individual students through a case study approach. Importantly, the goal of this project was to understand the process of active learning on a deep level (basic
Derek Braun, Monitoring Editor

Submitted Jan 14, 2019; Revised May 3, 2019; Accepted May 9, 2019

CBE Life Sci Educ September 1, 2019 18:ar33 DOI:10.1187/cbe.19-01-0006

tPresent address: Department of Science, Chatham University, Pittsburgh, PA 15232. *Address correspondence to: Lisa B. Wiltbank (lawiltbank@gmail.com).

(c) 2019 L. B. Wiltbank et al. CBE-Life Sciences Education ๑ 2019 The American Society for Cell Biology. This article is distributed by The American Society for Cell Biology under license from the author(s). It is available to the public under an Attribution-Noncommercial-Share Alike 3.0 Unported Creative Commons License (http://creativecommons.org/licenses/ by-nc-sa/3.0).

"ASCB®" and "The American Society for Cell Biology $® "$ are registered trademarks of The American Society for Cell Biology. 
research), rather than to prescribe far-reaching solutions or applications (applied research).

\section{Research Aim}

The overall aim of this study was to describe how students use in-class formative assessment and feedback to promote learning. In a recent publication (Wiltbank et al., 2019), we reported trends in students' responses to in-class feedback and how students used feedback to improve. Here, we report findings from further analysis of the same data set. The new analysis focused on variation between students, rather than trends across all students. This aim - to describe unique student responses to formative assessment-emerged organically as a result of student participants providing surprising and diverse responses to broad interview questions about in-class activities. A framework of active learning and student engagement, described below in Student Engagement during Active Learning, was applied to the data during the analysis phase and serves as a literature-based context to discuss key differences observed between students.

\section{Student Engagement during Active Learning}

Student engagement lies at the heart of successful active learning. Although definitions of active learning vary across the educational literature (Bonwell and Eison, 1991; Prince, 2004; Freeman et al., 2014; Cooper, 2016), most scholars agree that active pedagogies should engage students with course material during class. Consider the following well-cited definition from Prince (2004, p. 23):

Active learning is generally defined as any instructional method that engages students in the learning process. In short, active learning requires students to do meaningful learning activities and think about what they are doing.

To create the active-learning condition that Prince describes, a teacher provides "meaningful learning activities." A student then engages with these activities. Of particular importance is that the student engages on the cognitive level, which Prince (2004, p. 23) describes as, "think[ing] about what they are doing." Students' cognitive engagement is crucial, because the process of learning is fundamentally brain changing-a result of physical changes in brain cells (Owens and Tanner, 2017). Defining "cognitive engagement" is difficult, with decades of research yielding complex models of the phenomenon (Butler and Winne, 1995; Fredricks et al., 2004; Chi and Wylie, 2014). Rotgans and Schmidt (2011) provide an operational, student-centered definition that incorporates two basic tenets found across the literature, "Cognitive engagement is defined as the extent to which students are willing and able [emphasis added] to take on the learning task at hand" (p. 467).

First, a cognitively engaged student is willing to take on a learning task. On the most basic level, this requires that a student does not refuse to participate. However, even among the students who do participate, not all are willing to cognitively engage on a deep level with the goal of mastering biology (Pugh et al., 2009). Instead, some students operate on a surface level, trying to "get the task out of the way with minimum trouble, while appearing to meet course requirements" (Biggs and Tang, 2011, p. 24). Several reasons have been proposed for why students may refuse to engage deeply, such as lack of interest, high workloads, or assessment methods that reward surface learning (Dolmans et al., 2016).

Second, a cognitively engaged student is able to engage with the task. If a student lacks the background discipline-specific knowledge to understand the task, he or she may not be able to cognitively engage in a productive manner appropriate for the task (Alexander and Judy, 1988). A student's inability to productively engage is not always externally observable, as the student may still seem to be actively participating.

The relationship between cognitive engagement and student achievement is complex (Corno and Mandinach, 1983), but the literature generally supports a positive correlation between student engagement and performance (Trowler and Trowler, 2010; Upadyaya and Salmela-Aro, 2013). Thus, the literature posits links between active learning, engagement, and student performance. We examined these issues from the perspective of individual students in a high-enrollment introductory biology course.

\section{METHODS \\ Description of Class Context}

This research was conducted at a midwestern, land-grant university with higher research activity. Students in the study were enrolled in the first introductory biology course in a series of three courses required for life science majors. The content focus was the storage and movement of matter and energy across all biological levels (AAAS, 2011). Much of the class focused on molecular and cellular mechanisms, and the multiple-choice Introductory Molecular and Cell Biology Assessment (IMCA) was administered to students near the beginning and end of the semester (Shi et al., 2010). The classroom environment was a SCALE-UP classroom (Beichner et al., 2007), with 15 tables of nine students each. During class, students were given opportunities to complete in-class questions and activities, with help from peers, undergraduate learning assistants (Otero et al., 2010; Knight et al., 2015), and the instructor. Typically, the instructor provided feedback to the whole class after students completed an in-class question or activity.

\section{Data Collection}

Introductory biology students were invited to participate in five interviews at four time points throughout the semester (Figure 1). Full interview protocols are available in Wiltbank et al. (2019). Here, we provide a brief overview. Eight students in the target section of the class participated. Interviews focused on seven in-class activities. One participant withdrew early from the course, and thus was interviewed about only four of the in-class activities.

One interviewer-a graduate student or a postdoctoral fellow-conducted each interview. To our knowledge, students had never met the interviewer before the first interview. Interviews were structured with a common protocol across students (Wiltbank et al., 2019) to limit variation between interviewers and enable consistency across interview sets. The interviews were paired, with two interviews (interviews 1 and 2) conducted early in the semester and two interviews (interviews 3 and 4) conducted late in the semester. Interview 1 occurred soon after a biology class session early in the semester (Figure 1). Interview 3 occurred soon after a biology class session later in the semester (Figure 1). The class sessions for interviews 1 and 3 were videotaped and edited into short clips for use during 


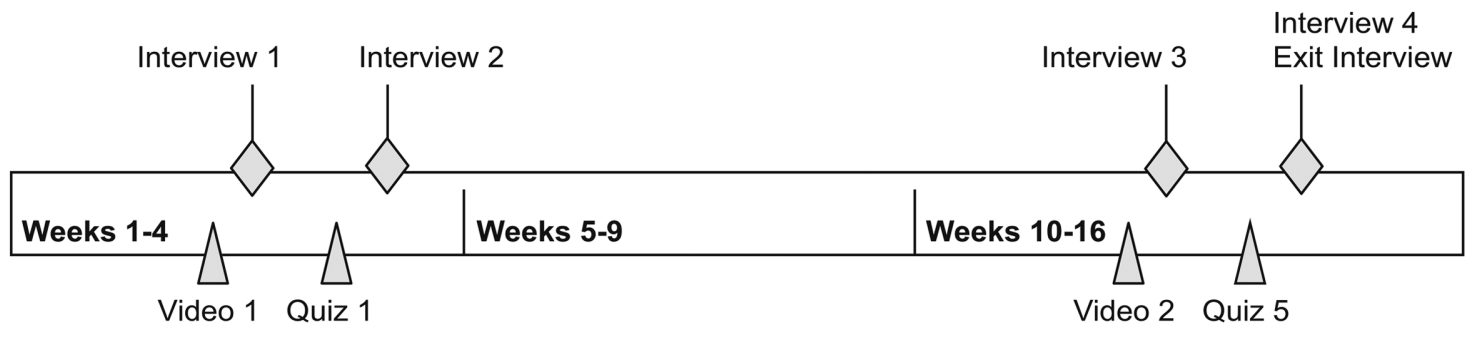

FIGURE 1. Timeline of stimulated recall interviews.

the interviews. Interviews 1 and 3 used the same interview protocol and only differed in the content of the class and timing during the semester. Briefly, students were shown a video clip of their instructor introducing an in-class problem or question and asked to reflect upon their experience in class while working on the problem or question. They were also prompted to specifically discuss in-class feedback. Interviews 2 and 4 (Figure 1) occurred after a summative quiz (examination) testing the students' knowledge of the material discussed in interviews 1 and 3 . Students watched the same video clips from the earlier interviews-clips from interview 1 were shown during interview 2 and clips from interview 3 were shown during interview 4 and were asked to "fill in the gap" between what happened after class and how class activities impacted their preparation for summative assessment. Finally, near the end of the semester, students participated in an exit interview, in which they reflected about in-class activities throughout the entire semester. All interviews were transcribed using Express Scribe software (NCH Software, Greenwood Village, CO).

\section{Data Analysis}

The data analysis process was a hybrid approach of 1) thematic analysis (Braun and Clarke, 2006) and 2) compiling case studies. At the outset of the analysis phase, we expected to rely solely on thematic analysis to determine commonalities between student perceptions of in-class activities and feedback. However, during phase 1 (first reading of interviews), we discovered interesting and striking differences between students. Thus, to represent the data accurately, we recognized the need to report unique student experiences in more depth. This warranted the writing of case studies based on the interview and performance data, as described in Phases 1 through 3 below.

Phase 1: First Reading. The goal of the first phase of analysis was to familiarize ourselves with the interview data and to record initial impressions. All interview transcripts, including those of the four students profiled in this report, were read by four researchers-an associate professor (J.L.M.), a postdoctoral fellow (L.B.W.), a graduate student (K.R.W.), and an undergraduate student (L.M.)—who wrote memos of their initial impressions and interpretations of each student's interviews. In an attempt to limit a priori ideas, readers were not given specific instructions about areas of emphasis or a common theoretical framework before reading the interviews. The four researchers met and discussed interview memos after the reading. Interviews were read and discussed in sets of two or three at a time. Individual readers' memos and notes from group discussions were compiled to generate a list of initial ideas and impressions for each student.
Phase 2: Initial Coding. The goal of the second phase was to determine the range and frequency of ideas in each student's interviews. The list of ideas generated from phase 1 was used as an initial framework for coding of the interviews, and new ideas were added during the coding process. Each interview was coded line by line by one researcher (L.B.W.), and codes for $44 \%$ of the interviews were checked by a second researcher (L.M.) to ensure accuracy and completeness. Phase 2 led to the development of more than 200 codes.

Phase 3: Compiling Case Studies. From phases 1 and 2, we discovered a wide disparity in student experiences, even when students were taking the same class from the same instructor. The goal of phase 3 was to capture the variation in student experiences by compiling case studies using evidence from three sources: 1) codes from interview transcripts (phase 2), 2) memos and discussion notes from four interview readers (phase 1), and 3) demographic and performance data (provided with IRB approval by the registrar's office and the course instructor).

The four students profiled in this report were chosen for in-depth analysis because they were remarkably illustrative of how the same active-learning events could be perceived differently by individual biology students. These four students were chosen from an interview pool of eight students from one class section of introductory biology. Brief summaries of the four interviewees who were not profiled in depth are available in Supplemental Table 1.

Profiled students were assigned the pseudonyms Charlie, Ashley, Jill, and Megan. Steps were taken to remove identifying information for the students and the instructor. Narratives are supplemented by performance data for each student (Table 1). Bolded text within quotes highlights student insights that were particularly useful to researchers in developing narratives. Each case concludes with researcher commentary and questions generated from the results.

Although it was impossible to include everything that each student said in a short case study, it was important that case studies included the most common ideas of each student's interviews. After case studies were compiled, they were approved by each reader from phase 1 . Case study narratives were then compared against the line-by-line coding from phase 2. If one or more of the student's most frequent codes (ideas) were not represented in the case studies, the case study was revised. For example, Ashley's case study narrative emphasized her criticism of the class and prior knowledge of the material, which were two of the most common codes from her interviews. However, during code 
TABLE 1. Information about students profiled in this report ${ }^{\mathrm{a}}$

\begin{tabular}{lcccccccccc}
\hline & $\begin{array}{c}\text { Course } \\
\text { grade }\end{array}$ & Quiz 1 & Quiz 3 & Quiz 5 & $\begin{array}{c}\text { Final } \\
\text { (group) }\end{array}$ & $\begin{array}{c}\text { IMCA } \\
\text { preclass }\end{array}$ & $\begin{array}{c}\text { IMCA } \\
\text { postclass }\end{array}$ & ACT & GPA & Gender \\
\hline Charlie & W & $30 \%$ & $47 \%$ & - & - & 8 & - & 18 & 3.00 & M \\
Ashley & $\mathrm{A}$ & $100 \%$ & $93 \%$ & $93 \%$ & $95 \%$ & 12 & 14 & 25 & 3.79 & $\mathrm{~F}$ \\
Jill & $\mathrm{B}$ & $90 \%$ & $93 \%$ & $100 \%$ & $67 \%$ & 12 & 16 & 32 & 3.80 & $\mathrm{~F}$ \\
Megan & $\mathrm{A}$ & $57 \%$ & $93 \%$ & $93 \%$ & $92 \%$ & 6 & 14 & 25 & 3.63 & $\mathrm{~F}$ \\
Student 5 & $\mathrm{A}$ & $93 \%$ & $100 \%$ & $100 \%$ & $93 \%$ & 12 & 20 & 29 & 4.00 & $\mathrm{~F}$ \\
Student 6 & $\mathrm{C}$ & $47 \%$ & $93 \%$ & $0 \%$ & $70 \%$ & 9 & 8 & 23 & 2.46 & $\mathrm{~F}$ \\
Student 7 & $\mathrm{B}$ & $67 \%$ & $85 \%$ & $87 \%$ & $82 \%$ & 11 & 17 & 29 & 3.40 & M \\
Student 8 & $\mathrm{B}$ & $93 \%$ & $86 \%$ & $70 \%$ & $60 \%$ & 6 & 12 & 29 & 3.60 & $\mathrm{~F}$ \\
Class median & $\mathrm{B}$ & $63 \%$ & $80 \%$ & $67 \%$ & $75 \%$ & 8 & 12 & 24 & 3.13 & NA \\
\hline
\end{tabular}

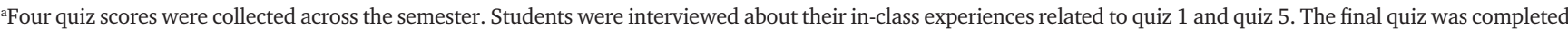
by students in groups of two or three students. The IMCA concept inventory is discussed in Methods. Grades were assigned on the scale A $=90-100 \%$, B $=80-89.9 \%$, $\mathrm{C}=70-79.9 \%, \mathrm{D}=60-69.9 \%, \mathrm{~F}<60 \%$.

checking we noticed that she was coded as saying "I was NOT confident, or I did not know how to do this" several times. After consulting her interview transcripts, we realized that these codes were mostly in relation to one in-class activity that was difficult for her. Thus, we added a description of that class activity to Ashley's case study narrative to more accurately represent her thoughts about her class experience as a whole. This same process of checking was done for each student's case study.

\section{Student Case Studies}

Student 1: Charlie. Charlie was a first-year student who entered college with the intention of becoming a doctor. He saw introductory biology as a stepping-stone to that career. From his first interview, Charlie expressed concern about his inability to understand course material. When he was asked about his experience during in-class group activities, his stress level was palpable, as illustrated by the following two quotes:

\footnotetext{
"It's just a roller coaster of emotions when [the teacher] asks questions 'cause you're like 'I know what this is,' and then you get it wrong and then you're 'I don't know what this is,' and then you panic 'cause [the teacher] can call on you and you're just worried and you can-the pressure probably rises, like, ten times in that class. A very unhealthy amount."
}

\begin{abstract}
"So what's happening in this question alone is figuring out the positive and negative charge of the element, of the atom alone, and then how it interacts with the other atom, and then figuring out if it will dissolve in water, or if it won't dissolve in water. And, if it does, then you gotta be able to draw the water molecule and draw it right-It's just a struggle, it's a struggle every single time."
\end{abstract}

Clearly, Charlie was feeling anxiety as a result of this class. Based on his relatively low scores on presemester standardized tests (Table 1) and his opinions expressed during interviews, it seemed that Charlie might have lacked the background knowledge required for success. He seemed confused about what to expect in a college-level biology class, and he discussed feeling frustration with the molecular and chemical topics covered at the beginning of the course:
"But this is only the first chapter in the chemistry section. I didn't sign up for this. I was like 'Where's my biology? Where's my frog dissection?' That's what I was told when you would go to biology class; you dissect things and you look at living things and plant cells, and this is NOT plant cells. This is chemistry. I don't need that."

Charlie had a mixed view of class activities. He sometimes expressed that he appreciated the in-class active learning and the feedback that he received, saying that they helped him learn new information or assured him that he understood:

"I think [talking to my peers] would-it teaches me what I'm looking out for in the material. I think being able to be like, 'Oh! I can't remember what a double bond is' and I'll be like, 'Oh, my tablemates were like it's when these two things happen."'

"Feedback? I think that we got feedback. Yes, after we were assured that the answer was $\mathrm{C}$ from the teacher, then [the teacher was] like, 'Oh, most of you got it! Good job!' And then [the teacher would] be like, 'So this is why-for the people who didn't get that right, 'Here, this is why.' And [the teacher will] tell us why, so it's good to hear that feedback. It wasn't a lot of feedback, but it's just like the reassuring 'You did it! Yay!' and then move on type thing."

However, more frequently, Charlie complained about the class activities and feedback, saying that he did not perceive them as being helpful for his learning:

"Feedback from the teacher is the usual: 'Oh this answer is 'D,' because this bond and that bond and blah, blah, blah, blah, blah."”

"I don't think this question or activity helped me to understand more the elements. Most of [the teacher's] questions and activities just in class don't really help us as students learn. I think that [the teacher] does this merely to make sure that we know what we're doing ... I think it's a way to kinda like get a quick information, a quick fact about it and then maybe apply to some other examples if you can, but I don't think that it's a good way to learn."

In the preceding quote, Charlie described the "quick information" that can be gleaned from in-class activities, but Charlie's 
lack of background knowledge seemed to make putting information into context difficult. Charlie profoundly summed up the experience of receiving feedback while feeling lost with the following description:

\begin{abstract}
"[Feedback would have been] helpful if I had known what I was doing and I would have understood what was happening, but for a person that didn't know what was happening, that information just hits them and just disappeared. You can't learn a whole thing by a sentence that a teacher tells you. Cause they can say 'Oh, you did it right because of this and this' and you're like 'okay, great' and then just, it doesn't stick, because you don't know what happened, you don't know how to use that information, you don't know if your brain got that information. So there's a lot of missing holes, if you don't get the information and when [the teacher] gives you the feedback, it's just, it's not going to stick."
\end{abstract}

Charlie received a poor mark on quiz 1 (Table 1). When asked about how he would prepare for the next quiz, he said the following:

"Yeah, really, really study for the next one. Just cause if-I did the math, sort of the math, and I figured that if I got, like, an average score of a B on every single test from that, I would be able to pass the class with a 'B.' Just cause, like, don't worry about this test, cause it's the first one and, like, it happens. And I'm like, 'No, because this is hard. This was really hard. It's not like usual. Is that normal?' So, like, if anything I would prepare more for the other tests, just so I can—so it balances my grade out."

Charlie eventually withdrew from the course and ultimately left the biology major. While reflecting about his performance on quiz 1 , he made a statement that foreshadowed those events:

"This particular test made me realize that maybe medicine or, like, biology isn't my major. So I guess I got that from it. I'm going to stick with it though 'cause I input too much time into it in high school. But it made me, I don't know, I won't major in biology now. Like, I was going to do that before. But it wasn't an idea, like, I had to do. But doing this class kind of was like, 'Should I? Should I really? Is this really what I want to do with my future?"'

Charlie's withdrawal from introductory biology was not the end of his academic endeavors. From the registrar, we know that Charlie changed majors. His new major capitalized on his excellent speaking skills and charisma, traits that were evident throughout his interviews. Charlie asked, "Is this normal?" when speaking of his difficulties in introductory biology. According to the registrar, Charlie had an overall grade point average (GPA) of 3.00 (a "B" average) after withdrawing from biology, suggesting that his struggles in biology were not "normal" for him, as he was not failing his other classes.

Commentary. Ultimately, the active-learning pedagogies in this class, despite all of their possible benefits, were not enough to empower Charlie to persist in his introductory biology course. His experience in introductory biology led him to declare, "biology isn't my major," and revise his plans. Recently, the U.S. Department of Education reported that roughly one- third of bachelor's degree-seeking students change their majors within the first 3 years, and the number is higher (nearly 40\%) for biology majors (Leu, 2017). Charlie provided us with a vivid, real-time account of his experience, which helped us to see that he was willing to engage with class activities but seemed to lack the background knowledge to reap their benefits. His account also offers a hopeful view of the opportunities open to Charlie after he left the biology major. What are the unique experiences of other students who, like Charlie, question their precollege goals by asking, "Is this really what I want to do with my future?"

Student 2: Ashley. Ashley had an antagonistic attitude that permeated her interviews. Perhaps the best example of this occurred at the end of the semester, when asked about her experience with our research project. The interview question was, "To your knowledge, did participating in these interview sessions impact you in any way? For example, what you studied, how you studied, how you approached class activities, or your response to feedback?" Ashley's answer was memorable:

\footnotetext{
"Um, yeah. I mean it didn't really help anything with the class itself. I guess, like, during class if something really, like, made me upset or if [the teacher] did something that I was like, 'Why is [the teacher] taking so long for this?' I was like, 'I'm gonna talk about this in my interview."'
}

True to her word, Ashley complained about many aspects of the class throughout the semester; for example, the pace, assessment methods, activities during class, group work as a pedagogical strategy, and the feedback that she and her classmates received during activities, as illustrated in the following two quotes:

"I feel like with the whole group discussion thing, we get so much less done than a lecture. And I mean I know there's like studies or whatever. We went over it at the beginning, like the very first day of class, we went over, like, lecture you only retain like blah-blah-blah, super low percent of what is being taught, but the problem is if you don't understand how to do these questions or if somebody next to you doesn't understand how to do the questions or you just don't understand how other people are trying to explain it to you, you're basically, like, screwed. I don't know. And then it's just kind of like a big waste of time, I feel like."

"I mean [the teacher] doesn't do a good job of, like, totally explaining why the answer's 'c.' I mean, because we totally run out of time ... And then if you're-if you don't understand, then you're kind of done for."

Ashley reported very limited study outside of class for both of the two quizzes we asked about:

Interviewer: So did you prepare for a question like this when you were studying?

Ashley: I didn't study, and I just knew how to do it. I had three exams in one day, so I had to pick and choose. 
Interviewer: Did you prepare for the topic? Or did you study the topic?

Ashley: I didn't study. [Laughs.] So, no. Yeah, I guess not then.

Ashley's combination of negative attitude and lack of studying may seem like a recipe for disaster. Indeed, Ashley often perceived that activities or feedback had no positive effect on her and did not lead to learning. When she did report positive events, these tended to be masked by negative caveats:

\begin{abstract}
"So for me every time we do group work, it kind of feels like I get the answer, like, instantly and then I just feel like I'm kind of, like, having to help other people, which is great. It's like a super good learning tool to help teach others. But for me, I get that, and so, and then it takes a long time to kind of move on to the next one, so I'm like always like, 'This will be like another four-minute time-waster!' you know.”
\end{abstract}

In the quote above, Ashley provided a clue to the reason for her caustic attitude: "it kind of feels like I get the answer instantly." This is not the only time that she expressed that sentiment. Ashley often reported that she already understood in-class activities before doing them, and she communicated confidence in her ability, as in the following quotes:

"For me, I mean, I'm not super duper smart but, like, I do fairly-I'm above average by a long shot, you know."

"I feel like nothing really changed [after doing this activity]. I mean, I don't know if-I feel like I didn't really learn anything. It was all just, like, previous knowledge from what I learned from reading the chapter or my old chemistry class."

Ashley's performance data support her claims of high efficacy in introductory biology. She did well on summative assessments throughout the semester (Table 1), and her course grade was one of the highest in the class. In a surprising exception to her pattern, on one occasion Ashley described a situation where she was not confident when doing a problem. This would seem to have been a time when active-learning strategies could have helped her. She recounted the incident in an interview conducted the day following the class where she struggled:

\section{Interviewer: So what were you doing and thinking during this} activity?

\begin{abstract}
Ashley: "I don't know what the heck is going on!" That's what I was thinking during this ... And then my table tried to explain it to me again and I was like, "Guys, this is not working." So then I called over [a learning assistant] and I mean she tried. I don't know. It was-I mean-she was-she tried. She knew what she was doing, but she didn't help me know what $I$ was doing. So, yeah.
\end{abstract}

In contrast, a few weeks later Ashley was asked about how she performed on a quiz item assessing the in-class activity she discussed in the last quote:

Interviewer: Did you prepare for a question similar to this [after class]?
Ashley: I should have a little bit more because I still don't really understand double bonds, how they just pop up, but-by some miracle of God-I got the answer right so, yeah.

Ashley received full credit on the quiz question. It was a multipart, application problem, and it is unlikely that Ashley could have guessed at the correct answer. Many students struggled on this problem, with a class average score of 50\%. In this example, Ashley did not "get the answer instantly." She also told us that she did not work to learn the concept. However, there were no consequences in terms of her performance on the test. She performed well despite her attitude and self-professed lack of outside effort.

Commentary. Judging by performance, Ashley was one of the most successful students in the class. But how much was she learning from any of the in-class exercises or the feedback? How much can a student learn if they already know the course content before class? Even if the instructor had provided engaging activities and delivered optimum feedback, these may not have impacted Ashley. She did not seem to think that she needed them.

In addition, it is important to remember that Ashley was interacting with other people during class. Unlike a lecture setting, where a student's bad attitude may be confined to a back corner of the room or conversations after class, an active-learning classroom is highly interactive. Overtly negative student perceptions have the potential to influence all students and members of the instructional team who interact with the student. Ultimately, what impact did Ashley have on others in this course? Was she a source of knowledge as a high-achieving peer or a source of negativity as a bored, frustrated critic?

Student 3: Jill. Jill reported liking most class activities, despite experiencing some of the same difficulties as Charlie and Ashley. Jill performed similarly to Ashley on preclass standardized tests and concept inventories (Table 1). Like Ashley, Jill found some in-class problems to be easy, as in the following two instances:

"I guess I pretty much felt like I understood pH and stuff. I
mean, having chemistry at the same time then we'd talk about
pH in that class, so I felt like I kinda had the whole concept
down."

"[The problem] was pretty easy. It was not-I don't know-it was pretty straightforward, obviously."

Unlike Ashley, Jill seemed to embrace the opportunity to work on class activities and receive feedback on these "straightforward" questions. The following three quotes are representative of Jill's response to in-class activities and feedback on those that she found to be easy or reviewing previous knowledge:

"I think it was helpful, like, to practice drawing bonds and stuff. I don't know if it will affect the way that I study, but I liked the practice, I guess."

"[The feedback] made it easier to understand and it was more, like, conceptual so it really helped get the concept and not necessarily just like, 'this is what a double bond is,' like we get why and where they belong and stuff like that." 
"My tablemate pointed out to me that if one stops then the whole thing slows down, and that can, like, very seriously impact your ATP production. So I'd say [this question] made it a lot-I don't know-just brought to light: Wow, there's a lot going on in cellular respiration!"

Unlike Charlie, Jill never expressed that she was completely lost during a class activity. However, she did have times when she was not confident. Instead of becoming frustrated, she seemed to use her mistakes to learn and prioritize difficult topics. The following incidents illustrate Jill's perspective as she worked through difficulties:

"When we talked about this as a table, there was one guy at my table who had a huge chain of all of these [atoms]. He had just linked them together because every time he would attach something, he would realize that one had an empty shell so he had to attach another one. It was just this big mess. That helped me, because I saw he was struggling, but then also I noticed that I messed up on a part of it, so it pressured me to study more and review more. That's kind of mean to say, seeing him mess up showed me that I needed to study more, but, still, he helped me realize where I had gone wrong and how to fix my mistakes."

"We had to talk to our tables and as a table we had to decide, decide on a molecule we would make and then we had someone draw it up front for everyone. We talked-we didn't just blurb on it like we did with the other [questions], where you just like talk about it for a few minutes and then move on, we stretched it out and really covered in depth how to build the molecule from the elements [the teacher] gave you."

Although she reported positive experiences with peers overall, Jill also noted that she sometimes struggled to get what she called "bystander" peers to participate, especially during group quizzes. This seemed to make it difficult for Jill to receive the full potential benefit of group work:

\footnotetext{
"So I felt like I was pretty much just, like, talking to a wall, because [my peers] didn't really answer my question or, like, even debate with me or think it through or anything, so that was kind of not helpful ... I mean, usually I'd try to be like 'What do you think?' you know, like, try to get a rise out of them, but it was like that usually never really happened. So it pretty much just turned into me just kind of, just not-I don't know-I felt like I didn't ask a lot of questions from then on out. I actually kind of just, like, took what I knew and went with it and just kinda let them tag along I guess."
}

For the grades that we collected, Jill's only low grade was on an assessment that she was required to complete with her group of peers (Table 1 ).

Jill discussed many times when feedback from the instructor was important for her. Feedback either reassured her that she was reasoning about a concept correctly or alerted her that she was wrong and showed her how to improve:

"[The teacher] came over and talked to us that was-like, [the teacher] explained to us what we were doing and how we had done this part right and this part wrong. And that helped because then we knew, oh we were doing good on this part and then we just have to change this and then we are doing really good, you know? So, that was helpful."

Unlike Ashley, Jill said that she studied for quizzes, and used in-class active-learning events to guide her practice:

"I liked that [the teacher] went over it in class and gave us a practice worksheet. That was a better way to study than learning all the vocab that the book threw at us. I would say that it definitely helped me study and that I did more practice problems in class than, like, looking at it and writing notes about it, so the practice problems helped a lot more."

Commentary. From Jill's account, she seemed dedicated to learning during class activities. She embraced opportunities for reinforcement of concepts and chances to learn from her mistakes by acknowledging them. Unlike Ashley, Jill did not receive an "A" in the class (Table 1). However, Jill described deliberately engaging in a process of learning during and after class that Ashley and Charlie did not describe. She seemed to be in what we call the "sweet spot," with the right combination of preparation and positive attitude to embrace active learning. A student with a positive outlook like Jill's would seem to be a great asset in the highly social environment of the active-learning classroom. In the end, it seems that Jill's grade suffered from her peer group's lack of participation. Meanwhile, other students in the same class were likely reaping the benefits of productive group discussions. The less-structured nature of active learning naturally introduces variability in each student's opportunities for valuable interactions and feedback with peers and instructors. What steps can teachers take to ensure that students like Jill, who are willing and able to engage, can receive the full benefit of active learning?

Student 4: Megan. When asked to reflect on her experience in biology at the end of the semester, Megan gave a textbook answer about how she benefited from active learning:

"I think it was the way [the teacher] taught the class was helpful and I was always trying to connect things and it helped my understanding, compared to just sitting in a lecture hall. I thought that was a lot more helpful 'cause I was always engaged and always doing something that was relevant to what we were learning."

\begin{abstract}
"So the teacher would always have us do interactive things like writing on the whiteboard or just asking us questions and answering, like making us think about, like tying things together that way. So that was helpful. And I feel like that is kind of the ideal."
\end{abstract}

By her own report, Megan's experience with in-class activities seemed to be a positive one. Additionally, she earned an "A," the highest possible mark in the course. Megan's increased score from pre- to postclass concept inventory (IMCA) score was also the highest in the class, another indicator of her learning (Table 1). Analyses of Megan's interviews throughout the semester provided more information about what her active-learning "success story" looked like in action. 
Megan worked methodically through practice problems, evident by her frequent discussion of what she called the "breaking down" of concepts or problems. She used this phrase to describe her experience during six out of seven class activities. The simplest definitions that she provided for "breaking down" were "going through the steps" and "going through each part of the problem." She also asserted that breaking down a problem helped her to gain a deeper understanding of the material:

"Instead of just trying to memorize the entire thing, like, figuring out why things happen, like I said before, breaking down into little parts so it makes sense and it's not trying to memorize. It's like knowing why things are happening in cellular respiration."

When Megan saw the instructor "breaking down" concepts, she seemed to recognize that it would be a valuable strategy for studying for the quizzes:

Interviewer: How did you study?

Megan: Kinda like the same as for the others. I just wrote out each stage and I broke it down into each step, each stage and that was helpful for this question.

Interviewer: And why did you choose to study that way?

Megan: Because [the teacher] told us that that was the most important thing to know and not just to memorize it and have a deeper understanding of what was going on.

Megan valued in-class explanations from all sourcesinstructor, learning assistants, and peers-and found them useful in helping her to learn how to do class problems:

\begin{abstract}
"[The teacher] broke it down a little bit for us and so in the simpler steps than just giving this problem and having us solve it, breaking it down, like, going through it and helping us remember, will help me when I do my homework or on a quiz."
\end{abstract}

"I went through [a practice problem] with an LA and she explained the charges to me and that made a lot of sense and-so, like, that helped me when I was doing this problem, remembering how I solved the similar one in my practice."

"Since I was confused, I kinda listened to my two group mates talk and, like, talk it over and, like, know what's going on. So I like tried to follow their process of thinking, so that helped me."

After Megan scored poorly on quiz 1, we asked her what she would do differently to study for the next quiz. She said that she would switch from passive study methods to active study methods:

"I would do more practice problems instead of just, like, looking them over, because I knew how to draw, like, one example of a molecule. But then when [the quiz] had me like rearrange them, I wasn't sure. So I guess I would do more practice problems like that."
Unlike other students who merely talked about the changes they should make to their study techniques, Megan reported implementing these changes. For quiz 5, she reported mostly active study. Her efforts seemed to have helped her perform better on later quizzes:

"When I was studying, I went through and I labeled each stage and where it occurred and where things were going to and from and wrote out in a paragraph. So that was helpful to know, kind of like track everything and then with like the hydrogens, so yeah, that was helpful."

Commentary. Megan reported cognitively engaging with learning tasks and received a high grade. Megan's account seems to reflect an active-learning success story. Overall, Megan gave the impression of being highly strategic, with the goal of meeting the teacher's expectations for the course. This might seem superficial; however, in Megan's case, meeting expectations encouraged deeper study strategies, because she recognized that the teacher's goal was for her "not just to memorize it," but to "have a deeper understanding of what was going on." Is Megan's experience as a cognitively engaged, high-achieving student common, or are there a wide array of strategies that could be equally productive?

\section{DISCUSSION}

\section{Students Varied in Their Willingness and Ability to Engage with Learning Tasks}

Drawing from the framework of student engagement during active learning presented at the outset of this paper, we discuss differences in students' willingness and ability to engage with in-class activities. Jill and Megan reported being willing and able to engage in course activities. Both reported engaging in class activities productively most of the time (Figure 2). They both expressed a generally positive attitude toward in-class activities, which they felt benefited their overall learning. There were differences in their class circumstances (different peers, different interactions with the instructor, etc.) and how they chose to engage during activities (writing down answers, asking questions, etc.), but nothing in their interviews or performance data suggested that they were unwilling or unable to engage with activities.

Charlie and Ashley, in contrast, reported obstacles to their full engagement with in-class activities. Charlie seemed unable to engage productively, while Ashley gave responses that indicated that she was unwilling/unmotivated to engage. One major obstacle for both students was their levels of prior knowledge. Ideally, in-class learning tasks encourage students to construct their own meaning by making connections between new knowledge from current class material and old (prior) knowledge that was established before class enrollment (Cooperstein and Kocevar-Weidinger, 2004). This integration of new information with prior knowledge is a key factor that indicates a student has moved beyond passively listening and has become actively engaged (Chi and Wylie, 2014). Charlie said that he lacked sufficient prior knowledge to have a framework on which to build connections to new material. Ashley saw all of the "new" knowledge from class as prior knowledge, so she lacked the building materials to form new connections. 


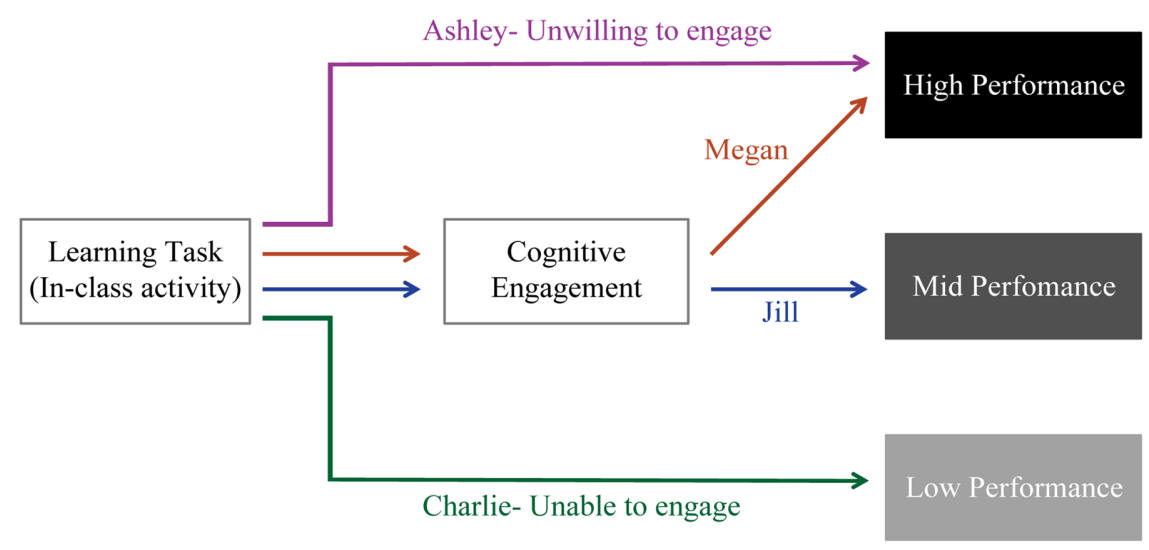

FIGURE 2. Summary model of trends observed for four biology students profiled in this report. Cognitive engagement was self-reported in interviews, and level of performance was determined by course grades $(90 \%$ or above $=$ high performance, $60 \%$ or below $=$ low performance, between 60 and $90 \%=$ mid performance).

Thus, Charlie was often unable to engage productively ("for a person that didn't know what was happening, that information just hits them and just disappeared"), and Ashley was often unwilling/unmotivated to engage ("it takes a long time to kind of move on to the next one, so I'm like always like, "This will be like another four minute time-waster!"'). This is depicted in Figure 2. Although Charlie and Ashley's assertions about their prior knowledge are merely their perceptions, both students' course grades generally correspond to their self-reported claims.

Charlie's dramatic illustration warrants more attention and a brief discussion of how institutions of higher learning may help bright, yet underprepared, students overcome the obstacles that Charlie experienced. Charlie's story highlights how lack of preparation seems to contribute to lower levels of persistence in science (Griffith, 2010; Waldrop, 2015). Some colleges and universities have tried to address this lack of preparation by providing summer bridge classes to help students before they enter the first year of university (Gilmer, 2007; Cabrera et al., 2013) and other programs provide scaffolding for students to complete science degrees (Rath et al., 2007; Toven-Lindsey et al., 2015). Perhaps if Charlie had access to one of these programs, it would have positively affected his experience in introductory biology.

\section{Grades Were Not a Complete Indicator of Individual Students' Success or Failure}

The potential to improve learning is one driving force for implementing active-learning pedagogies in the classroom. Measurement of the effectiveness of active pedagogies on learning is often detected by observing benefits in three outcome variables: lower failure and/or drop rates, improved learning gains on concept inventories (pre- and postclass), and higher course grades, including exam scores (Prince, 2004; Freeman et al., 2011; Haak et al., 2011). Clearly, these are valuable outcomes to consider. However, Cooper (2016, p. 799) suggested that "course grades do not measure the types of improvements that 'active learning' may promote." Other studies support this hypothesis, with benefits of active learning over lecture reported in areas such as problem-solving skills, critical thinking, attitudes about learning, and interpersonal communication (Bonwell and Eison, 1991; Anderson et al., 2005; Armbruster et al., 2009; Thaman et al., 2013).

Some students in our sample discussed non-grade benefits of active learning as they happened in an introductory biology class. Megan talked about how she enjoyed doing activities during class, which she believed "helped my understanding, compared to just sitting in a lecture hall." Jill said one class activity made her enthusiastically declare, "Wow, there's a lot going on in cellular respiration!" In fact, Jill expressed a sincere desire to learn the material throughout her interviews: trying to help those around her, learning from her mistakes, and participating fully during class.

Despite Jill's many non-grade successes of active learning, her effort was not rewarded with an "A." Jill's experience becomes more striking when compared with Ashley, an "A" student who reported that she did not put forth the type of effort that Jill discussed. These individual cases are not necessarily indicative of a widespread problem. However, they do suggest the possibility that grades are not a complete indicator of success. Despite her grade, it would be difficult to label Ashley's story as a "success" when she expressed little joy in the experience.

Charlie did not pass introductory biology, but, surprisingly, Charlie's case included many positives. Unlike some students who fail or withdraw, he was willing to engage during class activities. Additionally, although Charlie withdrew from biology with failing grades, his overall academic experience was not one of universal failure. He received high marks in other classes and changed his major to an area that emphasized social skills (a noticeable talent of his). Charlie's willingness to engage academically and his discovery of other interests were a success, even if his attempt to pass this particular biology class did not go as he originally planned.

Grades provide limited information about the student experience. A biology teacher or researcher examining the grades from this introductory biology class may label Charlie as a simple example of failure, Ashley as a simple example of success, and Jill as an inferior student compared with Ashley. All of these interpretations are, of course, more complicated when we take into account each students' unique abilities, attitudes, and situations. These case studies remind us that grades are a proxy and not an ultimate indicator of successful learning.

\section{Implications}

Before stating what we perceive as the broader implications of this study, we first issue a caution about what cannot be concluded. This study does not suggest that teachers of high-enrollment classes should ignore evidence from larger studies and change their overall teaching strategies to fulfill the unique needs of individual students. In fact, our data suggest the opposite. It would be difficult to envision an in-class lesson plan that would motivate Jill and guide Megan while also reaching Charlie and engaging Ashley. 
Our data supplement large quantitative studies by capturing aspects of the learning process that grades do not reveal. "Zooming in" on individual students uncovered how willingness and ability to cognitively engage affected each student's experience and provided a deeper context for interpreting each student's course grades. Analyzing each student's experience also introduced questions for future research, and some of these questions were presented at the end of each case study.

As a biology education community, we acknowledge that many impactful educational experiences result from teachers taking a genuine interest in each student's unique situation, when possible. Although idiosyncrasies of individual students are often not represented in the academic literature, educators should be careful not to rely too heavily on big data-such as surveys, inventories, and grades - and lose touch with their students as individuals. As Singh and Nath asserted in Research Methodology (2005), "Human nature is much more complex than the sum of its many discrete elements, even if they could be isolated and identified" (p. 25).

\section{ACKNOWLEDGMENTS}

We are grateful for the contribution of the student participants who shared their thoughts openly during interviews. We thank Rachel Salter for her tremendous assistance in conducting interviews, Ann Wiltbank for many valuable discussions, and members of the Momsen lab for their edits to earlier versions of the article. This work was funded by a grant from the National Science Foundation (DRL-1431891).

\section{REFERENCES}

Alexander, P. A., \& Judy, J. E. (1988). The interaction of domain-specific and strategic knowledge in academic performance. Review of Educational Research, 58(4), 375-404.

American Association for the Advancement of Science. (2011). Vision and change in undergraduate biology education: A call to action. Washington, DC.

Anderson, W. L., Mitchell, S. M., \& Osgood, M. P. (2005). Comparison of student performance in cooperative learning and traditional lecture-based biochemistry classes. Biochemistry and Molecular Biology Education, 33(6), 387-393.

Armbruster, P., Patel, M., Johnson, E., \& Weiss, M. (2009). Active learning and student-centered pedagogy improve student attitudes and performance in introductory biology. CBE-Life Sciences Education, 8(3), 203-213.

Beichner, R. J., Saul, J. M., Abbott, D. S., Morse, J. J., Deardorff, D. L., Allain, R. J., ... \& Risley, J. S. (2007). The Student-Centered Activities for Large Enrollment Undergraduate Programs (SCALE-UP) project. Physics Education Research, 1(1), 42.

Biggs, J., \& Tang, C. (2011). Teaching for quality learning at university. Maidenhead, UK: McGraw-Hill Education.

Bonwell, C. C., \& Eison, J. A. (1991). Active learning: Creating excitement in the classroom. Washington, DC: Washington University.

Braun, V., \& Clarke, V. (2006). Using thematic analysis in psychology. Qualitative Research in Psychology, 3(2), 77-101.

Butler, D. L., \& Winne, P. H. (1995). Feedback and self-regulated learning: A theoretical synthesis. Review of Educational Research, 65(3), 245-281.

Cabrera, N. L., Miner, D. D., \& Milem, J. F. (2013). Can a Summer Bridge program impact first-year persistence and performance? A case study of the New Start summer program. Research in Higher Education, 54(5), 481498.

Chi, M. T. H., \& Wylie, R. (2014). The ICAP framework: Linking cognitive engagement to active learning outcomes. Educational Psychologist, 49(4), 219-243.

Cooper, M. M. (2016). It is time to say what we mean. Journal of Chemical Education, 93(5), 799-800.
Cooperstein, S. E., \& Kocevar-Weidinger, E. (2004). Beyond active learning: A constructivist approach to learning. Reference Services Review, 32(2), 141-148.

Corno, L., \& Mandinach, E. B. (1983). The role of cognitive engagement in classroom learning and motivation. Educational Psychologist, 18(2), 88-108.

Dolmans, D., Loyens, S. M. M., Marcq, H., \& Gijbels, D. (2016). Deep and surface learning in problem-based learning: A review of the literature. Advances in Health Sciences Education: Theory and Practice, 21(5), 1087-1112.

Flyvbjerg, B. (2006). Five misunderstandings about case-study research. Qualitative Inquiry, 12(2), 219-245.

Fredricks, J. A., Blumenfield, P. C., \& Paris, A. H. (2004). School engagement: Potential of the concept, state of the evidence. Review of Educational Research, 74(1), 59-109.

Freeman, S., Eddy, S. L., McDonough, M., Smith, M. K., Okoroafor, N., Jordt, H., \& Wenderoth, M. P. (2014). Active learning increases student performance in science, engineering, and mathematics. Proceedings of the National Academy of Sciences USA, 111(23), 8410-8415.

Freeman, S., Haak, D., \& Wenderoth, M. P. (2011). Increased course structure improves performance in introductory biology. CBE-Life Sciences Education, 10(2), 175-186.

Gilmer, T. C. (2007). An understanding of the improved grades, retention and graduation rates of STEM majors at the Academic Investment in Math and Science (AIMS) program of Bowling Green State University (BGSU). Journal of STEM Education, 8, 11-21.

Gouvea, J. (2017). Insights from small-N studies. CBE-Life Sciences Education, 16(3), fe4.

Griffith, A. L. (2010). Persistence of women and minorities in STEM field majors: Is it the school that matters? Economics of Education Review, 29 911-922.

Haak, D. C., HilleRisLambers, J., Pitre, E., \& Freeman, S. (2011). Increased structure and active learning reduce the achievement gap in introductory biology. Science, 332(6034), 1213-1216.

Knight, J. K., Wise, S. B., Rentsch, J., \& Furtak, E. M. (2015). Cues matter: Learning assistants influence introductory biology student interactions during clicker question discussions. CBE-Life Sciences Education, 14(4), ar41.

Leu, K. (2017). Beginning college students who change their majors within 3 years of enrollment (No. 2018-434). Washington, DC: U.S. Department of Education, National Center for Education Statistics.

McLaughlin, J., \& Metz, A. (2016). Vision \& Change: Why it matters. American Biology Teacher, 78(6), 456-462.

Merriam, S. B. (2009). Qualitative research: A guide to design and implementation. San Francisco: Jossey-Bass.

Otero, V., Pollock, S., \& Finkelstein, N. (2010). A physics department's role in preparing physics teachers: The Colorado learning assistant model. American Journal of Physics, 78(11), 1218-1224.

Owens, M. T., \& Tanner, K. D. (2017). Teaching as brain changing: Exploring connections between neuroscience and innovative teaching. CBE-Life Sciences Education, 16(2), fe2.

Prince, M. (2004). Does active learning work? A review of the research. Journal of Engineering Education, 93(3), 223-231.

Pugh, K. J., Linnenbrink-Garcia, L., Koskey, K. L. K., Stewart, V. C., \& Manzey, C. (2009). Motivation, learning, and transformative experience: A study of deep engagement in science. Science Education, 94, 1-28.

Rath, K. A., Peterfreund, A. R., Xenos, S. P., Bayliss, F., \& Carnal, N. (2007). Supplemental instruction in introductory biology I: Enhancing the performance and retention of underrepresented minority students. CBELife Sciences Education, 6(3), 203-216.

Rotgans, J. I., \& Schmidt, H. G. (2011). Cognitive engagement in the problem-based learning classroom. Advances in Health Sciences Education: Theory and Practice, 16(4), 465-479.

Shi, J., Wood, W. B., Martin, J. M., Guild, N. A., Vicens, Q., \& Knight, J. K. (2010) A diagnostic assessment for introductory molecular and cell biology. CBE-Life Sciences Education, 9(4), 453-461.

Siggelkow, N. (2007). Persuasion with case studies. Academy of Management Journal, 50(1), 20-24.

Singh, Y. K., \& Nath, R. (2005). Research methodology. Delhi, India: A.P.H. Publishing. 
Thaman, R., Dhillon, S., Saggar, S., Gupta, M., \& Kaur, H. (2013). Promoting active learning in respiratory physiology-positive student perception and improved outcomes. National Journal of Physiology, Pharmacy and Pharmacology, 13(1), 27-34.

Toven-Lindsey, B., Levis-Fitzgerald, M., Barber, P. H., \& Hasson, T. (2015) Increasing persistence in undergraduate science majors: A model for institutional support of underrepresented students. CBE-Life Sciences Education, 14(2), ar12.

Trowler, V., \& Trowler, P. (2010). Student engagement evidence summary. York, UK: AdvanceHE.
Upadyaya, K., \& Salmela-Aro, K. (2013). Development of school engagement in association with academic success and well-being in varying social contexts. European Psychologist, 18(2), 136-147.

Waldrop, M. M. (2015). Why we are teaching science wrong, and how to make it right. Nature, 523, 272-274.

Wiltbank, L., Williams, K., Salter, R., Marciniak, L., Sederstrom, E., McConnell, M., ... \& Momsen, J. (2019). Student perceptions and use of feedback during active learning: A new model from repeated stimulated recall interviews. Assessment \& Evaluation in Higher Education, 44(3), 431448 . 